\title{
Project Based Learning dan Contextual Teaching and Learning Serta Gaya Belajar pada Ilmu Pengetahuan Alam
}

\author{
Lilies Mulyaningsih, Rufi'i, Djoko Adi Walujo \\ Universitas PGRI Adi Buana Surabaya \\ Teknologi Pendidikan, Pascasarjana, Universitas PGRI Adi Buana Surabaya
}

\section{Edcomtech}

\section{Jurnal Kajian}

Teknologi Pendidikan

Volume 6, No 1, April 2021

110-123

Submitted 11-05-2020

Accepted 11-06-2020

Corresponding Author

Lilies Mulyaningsih

Liliesmulyaningsih@gmail.com

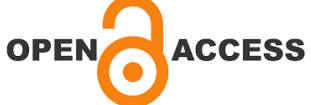

\begin{abstract}
Abstrak
Tujuan penelitian ini untuk mengetahui pengaruh pembelajaran PBL dan CTL terhadap kemampuan belajar IPA, mengetahui pengaruh gaya belajar terhadap kemampuan belajar IPA, dan mengetahui interaksi antara penerapan pembelajaran PBL dan CTL serta gaya belajar terhadap kemampuan belajar IPA. Metode penelitian ini menggunakan eksperimen desain penelitian treatment by level design. Populasi dalam penelitian sebanyak 6 kelas. Teknik pengambilan sampel dilakukan secara acak sederhana melalui nomor undian. Teknik analisis data menggunakan Anova dua jalur dengan nilai signifikansi sebesar $\alpha=0,05$. Hasil penelitian menunjukkan terdapat pengaruh pembelajaran PBL dan CTL terhadap kemampuan belajar IPA, tidak adanya pengaruh gaya belajar terhadap kemampuan belajar IPA, dan adanya interaksi antara pembelajaran PBL dan CTL serta gaya belajar terhadap kemampuan belajar IPA.
\end{abstract}

Kata kunci: PBL, CTL, Gaya Belajar, Kemampuan Belajar.

\begin{abstract}
The purpose of this study was to determine the effect of PBL and CTL learning on science learning abilities, determine the effect of learning styles on science learning abilities, and find out the interaction between the application of PBL and CTL learning and learning styles on science learning abilities. This research method uses experimental research design treatment by level design. The population in this study were 6 classes. The sampling technique is done by simple random sampling by lottery numbers. Data analysis technique used twoway Anova with a significance value of $\alpha=0.05$. The results showed that there was an effect of PBL and CTL learning on science learning abilities, there was no influence of learning styles on science learning abilities, and there was an interaction between PBL and CTL learning and learning styles on science learning abilities.
\end{abstract}

Keywords: PBL, CTL, Learning Style, Learning Ability. 


\section{LATAR BELAKANG}

Guna meningkatkan kualitas pembelajaran IPA, diperlukan pengembangan materi pembelajaran yang tepat dan berkualitas. Pada buku teks tematik kelas 5 muatan mata pelajaran IPA, sebagian materi yang disajikan di dalam buku tematik 5 muatan mata pelajaran IPA tersebut banyak yang menggunakan penalaran dari hal umum ke hal khusus, sehingga beberapa hal yang dialami siswa dalam belajar materi dari buku teks pelajaran tersebut kesulitan memahami. Proses belajar tentang IImu Pengetahuan Alam (IPA) yang diharapkan pihak sekolah, yaitu proses pembelajaran yang dapat mengembangkan keterampilan proses, pemahaman konsep, aplikasi konsep, sikap ilmiah, dan didasarkan kegiatan pembelajaran IImu Pengetahuan Alam (IPA) pada isu-isu yang dikembangkan di masyarakat (Astuti, Toto, \& Yulisma, 2019). Selain itu, materi yang disajikan mempunyai kekurangan seperti keterkaitan antara pembelajaran IPA menggunakan buku teks di sekolah dengan dunia nyata (real) dan kehidupan sehari-hari. Dalam proses belajar mengajar banyak terdapat faktor yang mempengaruhi tercapainya tujuan pembelajaran diantaranya pendidik, peserta didik, lingkungan, metode atau teknik serta media pembelajaran. Dalam kenyataannya, proses pengajaran yang berjalan atau berlangsung kurang efektif dan efisien dilakukan. Dikarenakan banyaknya waktu, dan tenaga yang terbuang percuma sedangkan tujuan dari pembelajaran tidak tercapai bahkan terjadi sesuatu yang tidak penting dalam komunikasi antara kedua belah pihak yaitu pendidik dan peserta didik.

Dengan adanya fasilitas media pembelajaran dan metode mengajar yang bervariatif maka tradisi lisan dan tulisan yang dilakukan dalam proses pembelajaran selama ini dapat diperkaya melalui berbagai media pembelajaran. Dengan adanya media pembelajaran, pendidik dapat menciptakan berbagai kegiatan yang memicu kreativitas, menentukan metode pengajaran yang akan dipakai dengan situasi yang berbeda dan menciptakan suasana emosional yang sehat diantara peserta didik (Thaariq, Lindawati, \& Puspita, 2020). Dengan demikian proses pembelajaran menjadi efektif dan efisien, sifatnya menjadi konkrit dan mudah dimengerti oleh peserta didik. Strategi model pembelajaran akan mempengaruhi hasil belajar sebagai pembelajaran yang berbasis proyek merupakan pendekatan pembelajaran kreatif dan inovatif, yang menekankan pada belajar kontekstual melalui kegiatan-kegiatan bersifat kompleks. Fokus pembelajaran terletak pada konsep maupun prinsip pokok dari suatu disiplin studi, yang melibatkan pebelajar dalam investigasi pemecahan masalah dan kegiatan tugas bermakna yang lain, memberi kesempatan kepada pebelajar bekerja secara otonom untuk mengkonstruksikan pengetahuan mereka sendiri, dan mencapai puncaknya yaitu menghasilkan produk nyata atau hasil karya (Hasibuan, 2014; Kuswandi, Surahman, Thaariq, \& Muthmainnah, 2018).

Project Based Learning (PBL) merupakan suatu bentuk pengajaran melalui kegiatan membuat project atau hasil karya, sehingga dengan project tersebut harapannya siswa belajar dari apa yang dilakukan, mencari cara agar projectnya berhasil, serta membuat siswa mengalami secara nyata dengan sendiri proses pembelajarannya dengan tetap dalam pengawasan dan bimbingan oleh guru. Sedangkan metode Contextual Teaching and Learning (CTL) merupakan cara belajar yang secara langsung terjadi dalam kehidupan sehari-hari. Sehingga siswa memiliki pengalaman belajar nyata yang membuat mereka ingat karena berhubungan dengan kehidupan sehari-hari. Guna meningkatkan hasil belajar dan juga memunculkan kreativitas siswa, maka kegiatan pembelajaran diharapkan perlu menciptakan sebuah inovasi kegiatan pembelajaran yang menyenangkan dan dapat mendorong siswa untuk mampu mengekspresikan kreativitasnya serta dapat meningkatkan hasil belajar siswa adalah melalui pembelajaran Project Based Learning. Untuk itu, peneliti menggunakan sebuah metode pembelajaran Project Based Learning (PBL) dan Contextual Teaching and Learning (CTL) serta gaya belajar siswa untuk meningkatkan kemampuan dan hasil belajar IPA pada materi perpindahan kalor. Pembelajaran yang aktif dan kreatif serta 
berpikir kritis dapat dilakukan guru dengan pembelajaran menggunakan strategi-strategi konstruktivistik yang memiliki potensi memberdayakan sebuah keterampilan berpikir kritis seperti pembelajaran berbasis project (Handini, Gusrayani, \& Panjaitan, 2016). Pembelajaran yang menekankan pembuatan proyek atau Project Based Learning (PBL) merupakan suatu pembelajaran yang menggunakan proyek/ kegiatan menghasilkan karya sebagai media. Peserta didik melakukan eksplorasi, penilaian, interpretasi, sintesis, dan informasi untuk menghasilkan berbagai macam bentuk hasil dari belajar. Project based learning atau pembelajaran berbasis penekanan sebuah proyek merupakan salah satu model pembelajaran yang berpusat pada siswa untuk melakukan suatu penyelidikan yang mendalam terhadap suatu permasalahan. Siswa secara konstruktif melakukan kegiatan pendalaman pembelajaran melalui pendekatan berbasis penelitian atau riset terhadap permasalahan yang berbobot, nyata, dan relevan dalam kehidupan sehari-hari.

Setiap penerapan pembelajaran yang dilakukan oleh guru memiliki tujuan dalam proses kegiatannya. Tujuan dari Project Based Learning, antara lain yaitu (a) Meningkatkan kemampuan peserta didik dalam pemecahan masalah proyek. (b) Memperoleh pengetahuan dan keterampilan baru dalam pembelajaran. (c) Membuat peserta didik lebih aktif dalam memecahkan masalah proyek yang bersifat kompleks dengan hasil produk nyata. (d) Mengembangkan dan meningkatkan keterampilan peserta didik dalam mengelola bahan atau alat untuk menyelesaikan tugas atau proyek. (e) Meningkatkan kolaborasi peserta didik khususnya pada $P B L$ yang bersifat secara kelompok. Model pembelajaran CTL menurut Sanjaya (2010) dinyatakan bahwa belajar dalam CTL bukan hanya sekedar kegiatan duduk, mendengarkan dan mencatat, tetapi belajar adalah sebuah proses pengalaman secara langsung. Pembelajaran kontekstual juga merupakan suatu pembelajaran yang mengaitkan sebuah mata pelajaran dengan situasi dunia nyata dalam kehidupan sehari-hari dan memotivasi siswa dalam membuat hubungan antara pengetahuan dan penerapannya dikehidupan sehari-hari. Lebih dari itu beliau membahas bahwa Contextual Teaching and Learning (CTL) merupakan suatu strategi pembelajaran yang menekankan kepada proses keterlibatan siswa secara penuh guna menemukan materi yang dipelajarinya dan menghubungkan dengan kondisi kehidupan nyata, sehingga siswa didorong untuk dapat menerapkannya dalam kehidupan mereka sehari-hari. Sedangkan Blanchard (Trianto, 2010) menyatakan bahwa pembelajaran kontekstual merupakan suatu pembelajaran yang terjadi dalam hubungan yang erat dengan pengalaman nyata atau sesungguhnya. Sementara Trianto (2010) berpendapatjuga mengenai $C T L$ adalah sebuah pembelajaran yang terjadi apabila siswa menerapkan dan mengalami apa yang sedang diajarkan dengan mengacu pada masalahmasalah secara nyata yang berhubungan dengan peran dan tanggung jawab mereka sebagai anggota keluarga dan bagian dari warga masyarakat. Sejalan dengan hal di atas, Muslich (2007) menjelaskan bahwa landasan filosofi CTL adalah bersifat konstruktivistik, yaitu filosofi belajar yang menekankan bahwa belajar tidak hanya sekedar menghafal tetapi membangun pengetahuan dan keterampilan baru lewat fakta-fakta yang mereka alami dalam kehidupannya sehari-hari. Dengan mengacu pada beberapa pendapat di atas, pembelajaran CTL merupakan suatu konsep pembelajaran yang mengaitkan antara materi pelajaran yang sedang dipelajari siswa dengan konteks dimana materi tersebut digunakan dengan menggunakan pengalaman dan pengetahuan sebelumnya untuk menemukan dan membangun pengetahuannya sendiri. Agar siswa mampu memecahkan masalah sebagai tujuan pembelajaran, maka dibutuhkan sebuah penerapan model yang sesuai dengan materi tujuan pembelajaran. Salah satunya yaitu model Project Based Learning (Insyasiska, Zubaidah, \& Susilo, 2017). Materi pelajaran akan bermakna bagi siswa jika mereka mempelajari materi tersebut melalui konteks kehidupan seharihari.

Pembelajaran yang berfokus pada tujuan penguasaan materi hanya berhasil dalam 
mengingat jangka pendek, tetapi kurang berhasil dalam membekali siswa guna memecahkan masalah dalam kehidupan jangka panjang. Model pembelajaran Contextual Teaching and Learning (CTL), memberikan sebuah bentuk pembelajaran yang dapat membantu guru mengaitkan antara materi yang diajarkan dengan kondisi dunia nyata siswa. CTL merupakan bentuk suatu pendekatan pembelajaran dengan menekankan pada proses keterlibatan siswa untuk menemukan materi yang ia pelajari dan menghubungkannya serta menerapkan dalam kehidupan mereka sehari-hari. Dengan kata lain, peran siswa dalam proses pembelajaran CTL adalah sebagai subjek pembelajar yang menemukan dan membangun sendiri konsep-konsep yang ia pelajari. Belajar bukan sekedar menghafal dan mengingat fakta saja, tetapi belajar merupakan upaya untuk mengoptimalkan potensi siswa melalui aspek kognitif, afektif, dan psikomotor.

$$
\text { Menurut Nurhadi (2002) CTL }
$$

merupakan sebuah konsep belajar yang mendorong guru untuk menghubungkan antara materi yang diajarkan dan kondisi dunia nyata pada siswa. Menurut Johnson (2002) CTL adalah bentuk proses pendidikan yang bertujuan menolong siswa melihat makna di dalam materi akademik yang mereka pelajari dengan cara menghubungkan subyek akademik dengan konteks dalam kehidupan sehari-hari. Pembelajaran kontekstual merupakan "konsep belajar yang mengaitkan antara materi yang diajarkannya dengan situasi dunia nyata siswa dan mendorong siswa membuat hubungan pengetahuan yang dimilikinya dengan penerapannya dalam kehidupan mereka seharihari, dengan melibatkan tujuh komponen utama pembelajaran efektif, yaitu: konstruktivisme (constructivism), bertanya (questioning), menemukan (inquiry), masyarakat belajar (learning community), pemodelan (modeling), dan penilaian yang sebenarnya (authentic assessment). Jadi pengertian CTL dari pendapat para tokoh-tokoh diatas dapat disimpulkan bahwa CTL adalah sebuah konsep pembelajaran yang membantu guru mengaitkan antara materi yang diajarkan dengan kondisi dunia nyata siswa dan mendorong siswa membuat hubungan antara pengetahuan yang ia miliki dengan penerapan dalam kehidupan seharihari. Menurut Fleming \& Mills (1992), gaya belajar adalah suatu kecenderungan siswa melakukan adaptasi strategi tertentu dalam belajarnya guna mendapatkan satu pendekatan belajar yang sesuai dengan tuntutan belajar di kelas atau di sekolah maupun tuntutan dari mata pelajaran. "An individual's preferred mode and desired conditions of learning" didefinisikan oleh Drummond (1998:186). Maksud dari pernyataan itu adalah gaya belajar dianggap sebagai cara belajar atau kondisi belajar yang disenangi oleh pebelajar. Willing (1988) mendefinisikan gaya belajar merupakan kebiasaan belajar yang disenangi oleh pebelajar. Keefe (1979) memberikan pandangan tentang gaya belajar sebagai cara seseorang dalam menerima, berinteraksi, dan memandang pada lingkungannya. Dunn dan Griggs (1988) memberikan pandangan gaya belajar sebagai karakter biologis bawaan dari seseorang. Gaya belajar atau learning style merupakan suatu karakteristik kognitif, afektif dan psikomotorik sebagai indikator yang bertindak relatif stabil untuk pebelajar merasa saling berhubungan dan bereaksi terhadap lingkungan belajar (NASSP dalam Ardhana dan Willis, 1989 : 4). Definisi yang lebih mendalam pada gaya belajar bahasa dan yang dijadikan panduan pada penelitian ini dikemukakan oleh Oxford (2001:359) yaitu gaya belajar didefinisikan suatu pendekatan yang digunakan peserta didik dalam belajar bahasa baru atau mempelajari berbagai mata pelajaran. Seorang siswa menangkap sebuah materi pelajaran ataupun informasi sesuai dengan gaya belajarnya, maka ia tidak akan merasa kesulitan (Elpira \& Ghufron, 2015; Thaariq, Surahman, Murti, Faqiroh, \& Kusworo, 2020). Gagne \& Briggs (1974) mengkaji permasalahan belajar yang kompleks serta menyimpulkan bahwa informasi dasar keterampilan sederhana yang dipelajari mempengaruhi terjadinya belajar yang bersifat lebih rumit. Dalam suatu proses pembelajaran juga harus dapat meningkatkan hasil belajar siswa. Hasil belajar juga menjadi tolak ukur berhasil atau tidaknya proses pembelajaran yang dilakukan dan menjadi evaluasi untuk perbaikan kedepannya (Gunawan \& Rahmah, 2019). Menurut Gagne ada lima kategori kemampuan belajar, yaitu: (1) Keterampilan intelektual. Yaitu kemampuan seseorang untuk 
berinteraksi dengan lingkungannya masingmasing dengan penggunaan lambang atau simbol. Kemampuan ini meliputi: (a) Asosiasi dan mata rantai atau menghubungkan suatu lambang dengan sebuah fakta. (b) Diskriminasi atau membedakan sebuah lambang dengan lambang lain. (c) Konsep atau pendefinisian suatu pengertian atau prosedur. (d) Kaidah atau kombinasi beberapa konsep dengan suatu cara. (e) Kaidah lebih tinggi atau menggunakan berbagai kaidah dalam memecahkan suatu masalah). (2) Strategi atau siasat kognitif. Keterampilan peserta didik untuk mengatur proses internal perhatian, belajar, ingatan, dan pikiran. (3) Informasi verbal. Kemampuan untuk mengenal dan menyimpan nama atau sebuah istilah, fakta, dan serangkaian fakta yang merupakan suatu kumpulan pengetahuan. (4) Keterampilan motorik. Keterampilan mengorganisasikan gerakan sehingga terjadi keutuhan gerakan yang mulus, teratur, dan tepat waktu. (5) Sikap. Keadaan dalam diri siswa yang mempengaruhi (bertindak sebagai moderator atas pilihan untuk bertindak). Sikap ini meliputi komponen afektif, kognitif, dan psikomotorik.

Kemampuan yang dimiliki siswa berbeda-beda setelah siswa menerima pengalaman belajarnya sendiri. Menurut Bloom (dalam Supridjono, 2012) hasil belajar meliputi kemampuan kognitif, afektif dan psikomotorik. Kemampuan kognitif terdiri dari knowledge (pengetahuan, ingatan); comprehension (pemahaman, menjelaskan, meringkas, contoh); application (menerapkan); analysis (menguraikan, menentukan hubungan); synthesis (mengorganisasikan, merencanakan); dan evaluating (menilai). Kemampuan afektif terdiri dari receiving (sikap menerima); responding (memberikan respon), valuing (nilai); organization (organisasi); characterization (karakterisasi). Kemampuan psikomotorik meliputi initiatory, pre-rountie, dan rountinized.

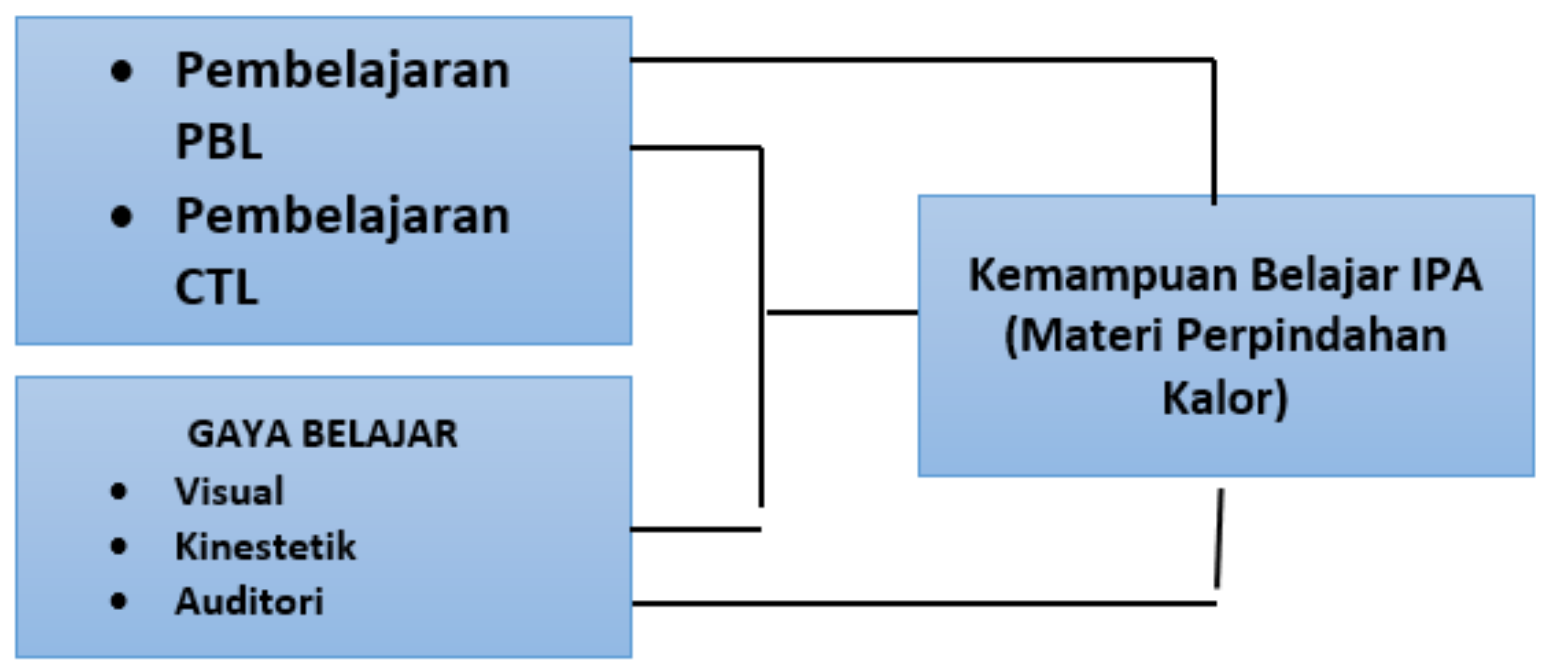

Gambar 1. Kerangka berpikir

Kerangka berfikir: (1) Penelitian menggunakan penerapan pembelajaran $P B L$ dan CTL serta gaya belajar terhadap kemampuan belajar IPA. (2) Pengaruh gaya belajar terhadap kemampuan belajar IPA. (3) Pengaruh interaksi penggunaan pembelajaran $P B L$ dan $C T L$ serta gaya belajar terhadap kemampuan belajar IPA.

Banyak penelitian yang dilakukan tentang penerapan pembelajaran CTL salah satunya penelitian sebelumnya yang dilakukan oleh Ledi Ahrisya (2019) di MI YPSM Al Manaar pada kelas 5 penggunaan pembelajaran CTL hasilnya dinyatakan bahwa ada perbedaan nilai rata-rata siswa sebelum dan sesudah menggunakan pembelajaran $C T L$ ini. tetapi yang kita lihat hanya sebatas penggunaan CTL saja. Dalam penelitian ini memiliki kebaruan yang kita lakukan karena penelitian menggunakan $P B L$ dan CTL serta 
gaya belajar siswa terhadap kemampuan belajar IPA.

\section{METODE}

Jenis penelitian ini merupakan penelitian yang bersifat kuantitatif, bentuk penelitian dilakukan secara sistematis, terstruktur, serta terperinci dengan penggunaan angka dan tabel untuk memaparkan hasil data yang diperoleh. Desain penelitian eksperimen yang digunakan adalah treatment by level design. Menurut Sukardi (2003: 16) penelitian ini banyak digunakan pada bidang ilmu pendidikan atau penelitian lain dengan subjek yang diriset adalah manusia. Pola treatment by level design dipergunakan untuk variabel moderator (kemampuan awal) karena dalam hal ini hanya model pembelajaran yang diberi perlakuan terhadap hasil belajar. Metode pengumpulan data dalam pengaruh pembelajaran $P B L$ dan CTL serta gaya belajar terhadap kemampuan belajar IPA siswa kelas 5 adalah: (a) Metode Observasi. Observasi dilakukan dengan cara pengamatan secara langsung, mencatat gejala-gejala yang yang terjadi pada objek penelitian secara keseluruhan dengan faktafakta di lapangan. (b) Metode dokumentasi. Dokumentasi dilakukan ketika penelitian itu berlangsung, dengan menggunakan kamera dan dokumentasi berupa lembar kerja siswa. (c) Metode Eksperimen. Eksperimen dilakukan dengan cara menerapkan secara langsung $P B L$ dan CTL dalam pembelajaran yang diterapkan kepada 2 kelas eksperimen, yang satu kelas dengan metode $P B L$ dan satu kelas yang lain menggunakan CTL serta memperhatikan gaya belajar siswa dalam memberikan materi pelajarannya. Populasi penelitian ini adalah 6 kelas yang terdiri dari siswa kelas 5 SDN Sidoklumpuk Sidoarjo dan siswa kelas 5 SDN Larangan Sidoarjo. Pengambilan sampel dalam penelitian berikut dilakukan menggunakan metode pengambilan acak sederhana melalui nomor undian di kelas 5 SDN Sidoklumpuk dan SDN Larangan Sidoarjo. Didapat 2 kelas $P B L$ dan 2 kelas CTL. Jadi ada 4 kelas sampel dengan jumlah total siswa 117. Data - data dianalisis menggunakan Statistik Anova 2 jalur dari hasil eksperimen. Analisis varians atau Anova merupakan suatu teknik inferensial yang digunakan untuk menguji rerata nilai. Anova mempunyai beberapa kegunaan, antara lain dapat mengetahui antar variabel manakah yang memang mempunyai perbedaan secara signifikan dan variabel manakah yang terjadi interaksi satu sama lain (Arikunto, 2014). Penelitian ini dilaksanakan pada tanggal 4 Januari 2020 sampai dengan tanggal 13 Maret 2020 di 2 (dua) sekolah yaitu SDN Sidoklumpuk Sidoarjo dan SDN Larangan Sidoarjo. Jumlah populasi penelitian sebanyak 117 siswa. Sampel penelitian ini adalah kelas 5 Sekolah Dasar dengan 4 (empat) kelas eksperimen. Teknik pengambilan sampel menggunakan teknik secara acak melalui nomor undian. Rinciannya adalah 2 kelas menggunakan metode pembelajaran $P B L$ dan 2 kelas berikutnya menggunakan metode pembelajaran CTL serta dalam pembelajaran ke 4 kelas tersebut langkah awalnya dengan memberikan angket gaya belajar untuk mengetahui dominan gaya belajarnya.

\section{HASIL DAN PEMBAHASAN}

Rincian jumlah kelas eksperimen dapat dilihat pada tabel berikut.

Tabel 1. Deskripsi Variabel Penelitian

\begin{tabular}{llll}
\hline \multicolumn{4}{c}{ Between-Subjects Factors } \\
\hline & \multicolumn{3}{c}{ Value Label } \\
\hline Metode Pembelajaran & 1 & $\mathrm{PBL}$ & 58 \\
\cline { 2 - 4 } & 2 & $\mathrm{CTL}$ & 59 \\
\hline Gaya Belajar Siswa & 1 & Visual & 32 \\
\cline { 2 - 4 } & 2 & Auditori & 62 \\
\cline { 2 - 4 } & 3 & Kinestetik & 23 \\
\hline
\end{tabular}


Dalam tabel 2. Deskripsi Variabel Penelitian diatas dari output SPSS 19 dapat kita lihat secara keseluruhan bahwa untuk penerapan $P B L$ berjumlah sebanyak 58 siswa, sedangkan untuk penerapan metode $C T L$ berjumlah sebanyak 59 siswa. Untuk Gaya belajar siswa yang dominan visual sebanyak 32 siswa, sedangkan untuk dominan gaya belajar auditori sebanyak 62 siswa, serta dominan gaya belajar kinestetik sebanyak 23 siswa. Secara garis besar pada penelitian ini dibagi menjadi 3 tahapan, yaitu: (1) Tahap persiapan. Pada tahap ini melakukan observasi gaya belajar siswa melalui pengisian sebuah angket gaya belajar yang berisi pernyataan dari nomor 1 sampai dengan nomor 15 . Nomor 1-5 menyatakan gaya belajar visual, nomor 6-10 menyatakan gaya belajar auditori, sedangkan nomor 11-15 menyatakan gaya belajar kinestetik. (2) Tahap pelaksanaan. Pada tahap pelaksanaan, kita memberikan penjelasan terlebih dahulu kepada siswa untuk kelasnya dijadikan eksperimen yang terbagi dari 2 kelas penerapan PBL dan 2 kelas penerapan CTL. Untuk penerapan $P B L$ siswa dibagi menjadi 6 kelompok setiap kelompok membuat project alat peraga yang membuktikan perpindahan panas/ kalor. Untuk kelas CTL kita mengajak siswa pembelajaran nyata di sekitar lingkungan sekolah yang membuktikan berbagai macam perpindahan kalor. (3) Tahap Evaluasi. Pada tahap evaluasi ini siswa diberikan post test berupa soal tertulis sebanyak 5 soal yang berhubungan dengan perpindahan kalor. Tujuan dari tahap evaluasi ini adalah mendapatkan data hasil belajar siswa setelah diberikan sebuah perlakuan. Data evaluasi ini adalah data akhir yang akan diuji pengaruhnya menggunakan Anova dua jalur.

\section{Uji Normalitas}

Uji Anova bertujuan untuk membandingkan sebuah perbedaan rata-rata pada kelompok yang telah dibagi menjadi dua variabel, yaitu variabel bebas dan variabel moderator. Uji normalitas digunakan untuk mengetahui pendistribusian data apakah normal atau tidak. Berikut adalah output hasil dari uji normalitas dengan menggunakan SPSS 19.

Tabel 2. Tes Normalitas

\begin{tabular}{|c|c|c|c|c|c|c|}
\hline \multicolumn{7}{|l|}{ Tests of Normality } \\
\hline & \multicolumn{3}{|c|}{ Kolmogorov-Smirnov ${ }^{a}$} & \multicolumn{3}{|c|}{ Shapiro-Wilk } \\
\hline & Statistic & $\mathrm{df}$ & Sig. & Statistic & $d f$ & Sig. \\
\hline $\begin{array}{l}\text { Standardized Residual } \\
\text { for Hasil }\end{array}$ & 181 & 117 & 190 & ,946 & 117 & 060 \\
\hline
\end{tabular}

a. Lilliefors Significance Correction

Sumber: Hasil perhitungan SPSS 19

Dasar dari pengambilan uji normalitas adalah: (1) Jika nilai sig $>0,05$ maka dikatakan nilai residual standar normal. (2) Jika nilai sig < 0,05 maka dikatakan nilai residual standar tidak normal. Hasil output SPSS 19 data standarized residual untuk hasil belajar menunjukkan angka statistic 0,19 > 0,05 pada KolmogorovSmirnov $^{a}$ Sedangkan pada Shapiro-Wilk menunjukkan nilai statistiknya 0,060 >0,05. Yang artinya data menyatakan berdistribusi normal yang kemudian selanjutnya kita melakukan uji homogenitas pada data tersebut.

\section{Uji Homogenitas}

Setelah dilakukan uji normalitas data, selanjutnya dilakukan tahap uji homogenitas. Uji ini dilakukan guna mengetahui varians antara 2 kelompok penerapan $P B L$ dan $C T L$. Syarat uji homogenitas adalah: (1) Jika nilai sig > 0,05 maka data dapat dikatakan homogen. (2) Jika nilai sig < 0,05 maka data dapat dikatakan tidak homogen 
Tabel 5. Hasil perbandingan rata-rata PBL dan CTL

\begin{tabular}{|c|c|c|c|c|}
\hline \multicolumn{5}{|c|}{ 1. Metode Pembelajaran } \\
\hline \multicolumn{5}{|c|}{ Dependent Variable:Hasil Belajar IPA } \\
\hline \multirow[t]{2}{*}{ Metode Pembelajaran } & \multirow[t]{2}{*}{ Mean } & \multirow[t]{2}{*}{ Std. Error } & \multicolumn{2}{|c|}{ 95\% Confidence Interval } \\
\hline & & & Lower Bound & Upper Bound \\
\hline PBL & 87,143 & 977 & 85,206 & 89,080 \\
\hline CTL & 96,453 & 1,069 & 94,334 & 98,572 \\
\hline
\end{tabular}

Pada output hasil belajar IPA perbandingan nilai hasil belajar $P B L$ diperoleh data nilai rata - rata uji sebesar 87,143 sedangkan nilai ratarata CTL sebesar 96,453. Dari perolehan ratarata tersebut, diketahui bahwa pembelajaran
$P B L$ dan $C T L$ memiliki perbedaan dan juga hasil belajar CTL menyatakan lebih tinggi dibandingkan pembelajaran PBL yang telah dilakukan.

Tabel 6. Hasil Perbandingan Gaya Belajar Siswa Terhadap Hasil Belajar IPA

\begin{tabular}{lllll}
\hline \multicolumn{4}{l}{ 2. Gaya Belajar Siswa } \\
\hline \multicolumn{4}{l}{ Dependent Variable:Hasil Belajar IPA } \\
\hline Gaya Belajar Siswa & Mean & Std. Error & \multicolumn{2}{l}{$95 \%$ Confidence Interval } \\
\cline { 3 - 5 } & & & Lower Bound & Upper Bound \\
\hline Visual & 92,188 & 1,259 & 89,693 & 94,682 \\
\hline Auditori & 93,067 &, 908 & 91,267 & 94,867 \\
\hline Kinestetik & 90,139 & 1,521 & 87,125 & 93,153 \\
\hline
\end{tabular}

Untuk perbandingan gaya belajar siswa terhadap hasil belajar IPA diperoleh nilai rata - rata sebesar 92,188 untuk gaya belajar visual. Perolehan data nilai rata - rata 93,036 untuk gaya belajar auditori. Dan perolehan nilai rata - rata 90,139 untuk gaya belajar kinestetik. Gaya belajar di dalam uji hipotesis Anova dua jalur menggunakan SPSS versi 19 tidak memiliki perbedaan secara signifikan sehingga dinyatakan hasilnya tidak ada perbedaan gaya belajar visual, auditori, ataupun kinestetik terhadap hasil belajar IPA.

Tabel 7. Hasil rata-rata PBL dan CTL terhadap Gaya Belajar Siswa

\begin{tabular}{|c|c|c|c|c|c|}
\hline \multicolumn{6}{|c|}{ 3. Metode Pembelajaran* Gaya Belajar Siswa } \\
\hline \multicolumn{6}{|c|}{ Dependent Variable:Hasil Belajar IPA } \\
\hline \multirow{2}{*}{$\begin{array}{l}\text { Metode } \\
\text { Pembelajaran }\end{array}$} & \multirow{2}{*}{$\begin{array}{l}\text { Gaya Belajar } \\
\text { Siswa }\end{array}$} & \multirow[t]{2}{*}{ Mean } & \multirow{2}{*}{$\begin{array}{l}\text { Std. } \\
\text { Error }\end{array}$} & \multicolumn{2}{|c|}{ 95\% Confidence Interval } \\
\hline & & & & $\begin{array}{l}\text { Lower } \\
\text { Bound }\end{array}$ & $\begin{array}{l}\text { Upper } \\
\text { Bound }\end{array}$ \\
\hline \multirow[t]{3}{*}{ PBL } & Visual & 87,500 & 1,780 & 83,973 & 91,027 \\
\hline & Auditori & 91,429 & 1,346 & 88,762 & 94,095 \\
\hline & Kinestetik & 82,500 & 1,903 & 78,729 & 86,271 \\
\hline \multirow[t]{3}{*}{ CTL } & Visual & 96,875 & 1,780 & 93,348 & 100,402 \\
\hline & Auditori & 94,706 & 1,221 & 92,286 & 97,125 \\
\hline & Kinestetik & 97,778 & 2,373 & 93,075 & 102,481 \\
\hline
\end{tabular}


Pada tabel 8. diatas memberikan gambaran perolehan nilai rata-rata perbandingan antara PBL dan CTL terhadap gaya belajar siswa. Diketahui bahwa pembelajaran CTL memberikan data nilai rata-rata lebih tinggi dibandingkan pembelajaran menggunakan PBL pada setiap gaya belajar visual, auditori, maupun gaya belajar pada kinestetik.

\section{PEMBAHASAN}

Pembahasan pada hasil penelitian ini terdapat pada variabel-variabel bebas (penerapan $P B L$ dan $C T L$ ), variabel moderator (gaya belajar), dan variabel terikat (kemampuan belajar) yang meliputi pengaruh penerapan Project Based Learning (PBL) dan penerapan Contextual Teaching and Learning $(C T L)$, pengaruh gaya belajar (visual, auditori, kinestetik) terhadap kemampuan belajar IPA, dan interaksi pengaruh pembelajaran Project Based Learning (PBL) dan Contextual Teaching and Learning (CTL) serta gaya belajar terhadap kemampuan belajar IPA. Pembahasan ini merupakan pendalaman eksperimen yang sudah dilakukan dan memberikan makna atau interpretasi terhadap implikasi yang terjadi. Data gaya belajar dan data hasil belajar selanjutnya kita analisis menggunakan Anova dua jalur, SPSS versi 19. Untuk syarat uji hipotesis menggunakan SPSS, kita harus melakukan uji normalitas dan homogenitas. Uji normalitas, didapat pada KolmogorovSmirnov $^{a}$ SPSS 19 nilai signifikan sebesar $0,190>0,05$ yang artinya uji normalitas terpenuhi. Untuk selanjutnya kita uji homogenitasnya. Dalam uji homogenitas didapat nilai signifikan sebesar 0,096 > 0,05 yang artinya uji homogenitas terpenuhi. Selanjutnya dilakukan uji hipotesis yang akan kita bahas berikut ini.

Dalam pengujian hipotesis pertama, pengujian analisis penerapan Project Based Learning $(P B L)$ diperoleh data keseluruhan rata - rata nilai hasil belajar sebesar 87,143. Sedangkan penerapan Contextual Teaching and Learning (CTL) sebesar 96,453. Selisih antara keduanya sebesar 9.31. Dengan mengetahui data nilai rata-rata keseluruhan, maka bisa dilihat bahwa nilai rata-rata penerapan pembelajaran Contextual Teaching and Learning (CTL) lebih tinggi dibandingkan penerapan Project Based Learning (PBL).

Uji hipotesis pertama adalah ada pengaruh perbedaan pembelajaran $P B L$ dan CTL terhadap kemampuan belajar IPA siswa kelas 5. Dasar dalam pengambilan keputusan dalam uji Anova dua jalur yaitu: Jika nilai signifikansi < 0,05, maka ada perbedaan hasil belajar berdasarkan variabel faktor dan jika nilai signifikansi $>0,05$, maka tidak ada perbedaan hasil belajar berdasarkan variabel faktor. Berdasarkan tabel 4.4 pada output SPSS 19 test of between - subjects effects diperoleh nilai signifikansi penerapan sebesar 0,000 yang artinya hasil uji hipotesis pertama menyatakan ada perbedaan pembelajaran $P B L$ dan CTL terhadap kemampuan belajar IPA siswa kelas 5. Penerapan CTL memberikan nilai lebih tinggi dibanding penerapan $P B L$. Model pembelajaran CTL adalah model pembelajaran yang menuntut kreativitas guru dalam mengaitkan subject matter dengan kehidupan nyata siswa guna membantu untuk lebih mudah memaknai materi tersebut. Hal ini relevan dengan penelitian yang dilakukan oleh Shoimin (2011) yang menyatakan pembelajaran CTL dapat menghadirkan situasi dunia nyata kepada siswa dan menjadikannya lebih bermakna.

Penggunaan model pembelajaran CTL membuat siswa menjadi lebih aktif pada proses pembelajaran karena ada tahapan dalam kegiatan yang dilakukan siswa. Hasil penelitian ini didukung oleh temuan penelitian yang telah dilakukan oleh peneliti sebelumnya (Abadiyah, Juanengsih, \& Fadlilah, 2017; Ahrisya, Praherdhiono, \& Adi, 2019; Amalia \& Rasiman, 2019; Siamy, Farida, \& Syazali, 2018; Susiloningsih, 2020)05, so that tcount $>$ ttable.. This result indicated that there was influence of contextual teaching and learning (CTL. Peneliti-peneliti tersebut berpendapat bahwa penerapan CTL lebih efektif, berpengaruh meningkatkan kemampuan belajar, dan siswa lebih memaknai. Dari aktifitas siswa yang lebih aktif memberikan kepastian bahwa hasil belajar juga akan lebih meningkat. Siswa lebih memberikan makna pembelajaran ketika siswa terlibat secara langsung dalam proses pembelajaran tersebut.

Pembelajaran kontekstual mempunyai tujuan mempermudah siswa 
dalam memahami isi pada pembelajaran yang ia dijalani, mengerti materi yang disampaikan dengan pengalaman belajarnya, dan proses pembelajaran akan lebih disenangi siswa dengan tanpa membuat siswa merasa bosan. Model pembelajaran kontekstual ini merupakan sebuah rancangan pembelajaran yang dilakukan dengan melibatkan materi pembelajaran pada situasi dunia nyata dan pengalaman belajar yang dialami oleh peserta didik. Dalam penelitian yang

dilakukan oleh Surahman, Wedi, Sulthoni, Soepriyanto, \& Setyosari (2018)reviewing and seeking answers to all the problems they face. To change the conventional learning paradigm, educators and students must jointly improve the...","event":"International Conference on Education and Technology (ICET 2018 CTL dapat dikombinasikan dalam pembelajaran berbasis proyek atau $P B L$. Tetapi dalam penelitian ini ditemukan pembelajaran $P B L$ memberikan hasil belajar yang baik tetapi hasil belajarnya masih lebih besar pembelajaran yang menggunakan CTL. $\mathrm{Hal}$ itu dikarenakan kemungkinan adanya faktor-faktor yang mempengaruhinya antara lain pada $P B L$ siswa butuh pendahuluan memahami konsep-konsep dasarnya sebelum membuat projectnya. Pembelajarannya hanya sekali waktu yang berbeda dengan CTL yang sangat berhubungan dengan kehidupan sehari - hari. Dalam berbagai penelitian ditemukan proses pembelajaran Contextual Teaching and Learning (CTL) dapat meningkatkan kemampuan belajar, khususnya pada kemampuan belajar IPA.

Pengujian hipotesis kedua membahas tentang terdapatnya pengaruh gaya belajar terhadap kemampuan belajar IPA . Gaya belajar yang kita amati terdiri dari 3 (tiga) jenis yaitu gaya belajar visual, auditori, dan kinestetik. Gaya belajar visual sebanyak 32 siswa, Gaya belajar auditori sebanyak 62 siswa, dan gaya belajar kinestetik sebanyak 23 siswa. Berdasarkan data hasil analisis tentang gaya belajar pada tabel 4 . 6 jumlah nilai rata - rata siswa yang gaya belajar visual sebesar 92,188. Jumlah nilai rata - rata siswa yang gaya belajar auditori sebesar 93,067. Kemudian nilai rata - rata siswa yang gaya belajarnya kinestetik sebesar 90,139. Dasar dalam pengambilan keputusan dalam uji Anova dua jalur yaitu jika nilai signifikansi < 0,05, maka dapat dikatakan ada perbedaan gaya belajar berdasarkan variabel faktor. Jika nilai signifikansi $>0,05$, maka dapat dikatakan tidak ada perbedaan gaya belajar berdasarkan variabel faktor. Berdasarkan hasil uji Anova dua jalur dalam tabel 4.4 pada output SPSS 19 test of between - subjects effects diperoleh nilai signifikansi gaya belajar sebesar 0,259 < 0,05 yang artinya tidak ada perbedaan gaya belajar terhadap kemampuan belajar IPA siswa kelas 5. Apapun gaya belajarnya, tidak akan mempengaruhi kemampuan belajar IPA siswa kelas 5 pada penelitian ini.

Dalam beberapa penelitian yang kita temukan gaya belajar sangat mempengaruhi peningkatan hasil kemampuan belajar dan juga gaya belajar merupakan suatu hal yang dianggap sangat penting dalam pembelajaran, dikemukakan oleh Bire, Geradus, \& Bire (2014) dan Sari (2014). Tetapi hasil penelitian ini tidak sejalan dengan pendapat beliau. Justru bertolak belakang. Hasilnya apapun gaya belajar siswa tidak memberikan pengaruh terhadap kemampuan belajar IPA. Tidak ada perbedaan dalam kemampuan belajarnya. Hasil penelitian ini juga tidak sesuai dengan pendapat gaya belajar merupakan sebuah cara paling mudah yang dimiliki oleh individu untuk menyerap, mengatur, dan mengolah informasi yang diterima. Gaya belajar yang sesuai merupakan kunci keberhasilan siswa dalam kegiatan belajarnya. Dengan memahami hal ini, siswa dapat mampu menyerap dan mengolah informasi serta menjadikan belajar lebih mudah dengan memperhatikan gaya belajar siswa sendiri. Terdapat tiga tipe dalam gaya belajar yaitu visual, auditorial, dan kinestetik (Deporter \& Hernacki, 2000). Gaya belajar merupakan suatu hal yang sangat penting. Informasi yang berhubungan dengan karakteristik gaya belajar siswa yang akan mengikuti proses belajar mengajar, sangat penting bagi guru untuk meningkatkan kualitas proses pembelajarannya. Hasil dalam penelitian ini tidak sejalan dengan yang dilakukan oleh (A. Johnson \& Miller, n.d.) yaitu gaya belajar siswa ditentukan oleh karakteristik bidang 
ilmu yang diambilnya. Apapun karakteristik pembelajaran IPA pada materi perpindahan kalor ini, hasilnya tidak ada perbedaan.

Pembahasan uji hipotesis yang ketiga adalah pengujian interaksi antara pembelajaran $P B L$ dan $C T L$ serta gaya belajar terhadap kemampuan belajar IPA siswa kelas 5. Dasar dalam pengambilan keputusan pada uji Anova dua jalur yaitu jika nilai signifikansi $<0,05$, maka dapat dikatakan ada perbedaan interaksi berdasarkan variabel faktor. Jika nilai signifikansi $>0,05$, maka dapat dikatakan tidak ada perbedaan interaksi berdasarkan variabel faktor. Berdasarkan hasil uji Anova dua jalur dalam tabel 4.4 pada output SPSS 19 test of between - subjects effects diperoleh nilai signifikansi penerapan pembelajaran $P B L$ dan CTL serta gaya belajar sebesar 0,003 $<0,05$ yang artinya terdapat interaksi antara pembelajaran $P B L$ dan $C T L$ serta gaya belajar terhadap kemampuan belajar IPA siswa kelas 5. Hal ini sejalan dengan hipotesis yang kita lakukan. Perlakuan pada pembelajaran PBL dan CTL serta gaya belajar memiliki dampak terhadap kemampuan belajar IPA. Komponen variabel bebas, variabel moderator, dan variabel terikat tidak lepas dari interaksi. Yamin (2010), menyatakan interaksi pembelajaran merupakan suatu kegiatan komunikasi yang dilakukan secara timbal balik yang merupakan dampak dari sebab akibat. Dari sebab akibat itulah terjadi sebuah interaksi.

\section{SIMPULAN}

Berdasarkan hasil penelitian dan pembahasan yang dikemukakan sebelumnya, Penelitian ini dapat disimpulkan bahwa: Terdapat perbedaan pembelajaran $P B L$ dan CTL terhadap kemampuan belajar IPA siswa kelas 5 , Tidak ada pengaruh gaya belajar terhadap kemampuan belajar IPA siswa kelas 5, dan Terdapat pengaruh antara pembelajaran $P B L$ dan CTL serta gaya belajar terhadap kemampuan belajar IPA siswa kelas 5 .

Cakupan pada materi perpindahan kalor dalam kehidupan sehari-hari sangat luas, diharapkan untuk para guru SDN Larangan dan SDN Sidoklumpuk Sidoarjo selalu meningkatkan kemampuan belajar siswa dengan menggunakan pembelajaran
Contextual Teaching and Learning (CTL) pada materi perpindahan kalor, pelajaran IPA siswa kelas 5. Dengan menerapkan pembelajaran CTL siswa mempunyai pengalaman belajar yang bermakna dan mudah diingat karena bersinggungan dengan kehidupan seharihari. Berdasarkan hasil penelitian ini, pengaruh pembelajaran CTL sangat tinggi dalam meningkatkan kemampuan belajar siswa kelas 5. Untuk itu perlu dilakukan upaya mensosialisasikan pembelajaran CTL ini khususnya pada materi perpindahan kalor melalui Kelompok Kerja Guru (KKG) atau pelatihan-pelatihan guru yang lain. Upaya penerapan pembelajaran ini perlu dikembangkan untuk memacu guru dalam melaksanakan pembelajaran yang bervariatif guna meningkatkan kemampuan belajar siswa.

\section{REFERENSI}

Abadiyah, F., Juanengsih, N., \& Fadlilah, D. R. (2017). The Effect of Contextual Teaching and Learning Combined with Peer Tutoring towards Learning Achievement on Human Digestive System Concept. Jurnal Penelitian Dan Pembelajaran IPA, 3(2), 101-111. doi: 10.30870/jppi.v3i2.1959

Ahrisya, L., Praherdhiono, H., \& Adi, E. P. (2019). Pengaruh Model Pembelajaran Contextual Teaching and Learning (CTL) Terhadap Hasil Belajar Siswa Kelas V Pada Tema 9 Subtema 1 di MI YPSM Al Manaar. Jurnal Kajian Teknologi Pendidikan, 2(4), 306-314. doi: 10.17977/um038v2i42019p306

Amalia, Y., \& Rasiman, R. (2019). Pengaruh Model CTL (Contextual Teaching Learning) dengan Media Pohon Hitung terhadap Hasil Belajar Materi Operasi Hitung. International Journal of Elementary Education, 3(2), 186-193. doi: $10.23887 /$ ijee.v3i2.18525

Arikunto, S. (2014). Prosedur Penelitian: Suatu Pendekatan Praktik. Jakarta: Rineka Cipta.

Astuti, I. D., Toto, T., \& Yulisma, L. (2019). Model Project Based Learning (Pjbl) Terintegrasi Stem Untuk Meningkatkan Penguasaan Konsep Dan Aktivitas 
Belajar Siswa. Quagga: Jurnal Pendidikan Dan Biologi, 11(2), 93-98.

Bire, A. L., Geradus, U., \& Bire, J. (2014). Pengaruh gaya belajar visual, auditorial, dan kinestetik terhadap prestasi belajar siswa. Jurnal Kependidikan: Penelitian Inovasi Pembelajaran, 44(2). doi: 10.21831/jk.v44i2.5307

Deporter, B., \& Hernacki, M. (2000). Quantum pathways: Discovering your personal learning style. Learning Forum Publications.

Elpira, N., \& Ghufron, A. (2015). Pengaruh penggunaan media powerpoint terhadap Minat dan hasil belajar ipa siswa kelas IV SD. Jurnal Inovasi Teknologi Pendidikan, 2(1), 94-104.

Fleming, N. D., \& Mills, C. (1992). Not another inventory, rather a catalyst for reflection. To Improve the Academy, 11(1), 137-155.

Gagne, R. M., \& Briggs, L. J. (1974). Principles of instructional design. Holt, Rinehart \& Winston.

Gunawan, Z., \& Rahmah, A. (2019). Contextual Teaching And Learning Approaches And Its Application In PAI Learning. Jurnal Pedagogik, 6(2), 557-592.

Handini, D., Gusrayani, D., \& Panjaitan, R. L. (2016). Penerapan model contextual teaching and learning meningkatkan hasil belajar siswa kelas IV pada materi gaya. Jurnal Pena IImiah, 1(1), 451-460.

Hasibuan, M. I. (2014). Model Pembelajaran CTL (Contextual Teaching and Learning). Logaritma: Jurnal Ilmu-IImu Pendidikan Dan Sains, 2(01).

Insyasiska, D., Zubaidah, S., \& Susilo, H. (2017). Pengaruh project based learning terhadap motivasi belajar, kreativitas, kemampuan berpikir kritis, dan kemampuan kognitif siswa pada pembelajaran biologi. Jurnal Pendidikan Biologi, 7(1), 9-21.

Johnson, A., \& Miller, J. (n.d.). Comparison of student's learning style in STEM discipline. Presented at the Proceedings of the Industrial Engineering Research Conference.

Johnson, E. B. (2002). Contextual teaching and learning: What it is and why it's here to stay. Corwin Press.

Kuswandi, D., Surahman, E., Thaariq, Z. Z. A., \& Muthmainnah, M. (2018). K-Means Clustering of Student Perceptions on Project-Based Learning Model Application. 2018 4th International ConferenceonEducationandTechnology (ICET), 9-12. Malang, Indonesia: IEEE. doi: 10.1109/ICEAT.2018.8693932

Muslich, M. (2007). KTSP: pembelajaran berbasis kompetensi dan kontekstual, panduan bagi guru, kepala sekolah, dan pengawas sekolah. Bumi Aksara.

Nurhadi. (2002). Pendekatan Kontekstual (CTL). Malang: Universitas Negeri Malang.

Sanjaya, W. (2010). Strategi Pembelajaran Berorientasi Standar Proses Pendidikan. Jakarta: Kencana.

Sari, A. K. (2014). Analisis Karakteristik Gaya Belajar VAK (Visual, Auditorial, Kinestetik) Mahasiswa Pendidikan Informatika Angkatan 2014. EduticScientific Journal of Informatics Education, 1(1).

Siamy, L., Farida, F., \& Syazali, M. (2018). Media Belajar Matematika Berbasis Multimedia Interaktif dengan Pendekatan Contextual Teaching and Learning. Desimal: Jurnal Matematika, 1(1), 113-117. doi: 10.24042/djm. v1i1.1919

Supridjono, A. (2012). Cooperative Learning: Teori dan Aplikasi Paikem. Yogyakarta: Pustaka Belajar.

Surahman, E., Wedi, A., Sulthoni, Soepriyanto, Y., \& Setyosari, P. (2018, December). Design of Peer Collaborative Authentic Assessment Model Based on Group Project Based Learning to Train Higher Order Thinking Skills of Students. 75-78. Atlantis Press. Retrieved from https:// www.atlantis-press.com/proceedings/ icet-18/125926623

Susiloningsih, W. (2020). Model Pembelajaran CTL (Contextual Teaching and Learning) dalam Meningkatkan Hasil Belajar Mahasiswa PGSD Pada MataKuliah Konsep IPS Dasar. PEDAGOGIA: Jurnal Pendidikan, 5(1), 57-66.

Thaariq, Z. Z. A., Lindawati, L., \& Puspita, R. 
D. (2020). Profesionalitas Guru Sekolah Dasar dalam menghadapi Ragam Karakteristik Belajar. EduBasic Journal: Jurnal Pendidikan Dasar, 2(1), 61-71.

Thaariq, Z. Z. A., Surahman, E., Murti, S. A., Faqiroh, B. Z., \& Kusworo, N. R. (2020). Analysis of Learners Characteristics and Learning Process Preferences during Online Learning. 1st International
Conference on Information Technology and Education (ICITE 2020), 49-54. Atlantis Press.

Trianto. (2010). Model Pembelajaran Terpadu Konsep, Strategi, dan Implementasinya dalam Kurikulum Tingkat Satuan Pendidikan (KTSP). Jakarta: Bumi Aksara. 